\title{
WETLAND LOSS IN ASPEN PARKLAND OF SASKATCHEWAN
}

\author{
JORDAN IGNATIUK and DAVID C. DUNCAN, Saskatchewan Wetland \\ Conservation Corporation, Room 110, 2151 Scarth St., Regina, SK. S4P $3 Z 3$
}

Wetlands are some of the most productive ecosystems, providing a multitude of benefits including ground water recharge, soil and water conservation, flood prevention and wildlife habitat. Most of these benefits accrue to society at large. Wetlands can also be obstacles to farming and development, and may represent lost economic opportunity. Most of these costs are borne by the landowner. Wetlands in Saskatchewan have been and continue to be destroyed. Although some land use changes on wetlands have been documented and reviewed across Canada, ${ }^{7}$ estimates of actual loss of wetlands has not been intensively studied in Saskatchewan. This study attempts to estimate the percentage of wetlands permanently lost in Saskatchewan from the late 1940s to the present, and compares these results to other studies.

Methods Quarter sections were randomly selected from five regions of the province which fall within key program areas for the North American Waterfowl Management Plan (NAWMP) $^{16}$ in Saskatchewan (Table 1). Historical air photos were obtained from Central Survey and Mapping Agency at a scale of $1: 15,000$. The oldest available photos were used, the majority of which $(75-80 \%)$ were from 1947 and 1949. Recent aerial photographs (1986-1992) at a scale of $1: 20,000$ were obtained from Ducks Unlimited Canada for com- parison. Photos were enlarged $200 \%$ on a laser photocopier, which preserved the clarity and definition of the original photo, to enhance detection of wetlands.

Wetlands were delineated as any depression or basin which was covered by water, at least periodically. Numbers of wetlands were counted independently on both the old and new photos and compared side by side to assist in discriminating wetlands and determining loss. Loss was defined as total obliteration (ie. drained and filled). Total number of wetlands and average per quarter section were determined for each region. Percentage loss of wetlands is reported for each region and overall. A comparison with ground-truthed transects conducted under the Prairie Pothole Project in the Redvers area was made to calibrate the accuracy of this study in identifying wetlands from photos.

Results A total of 2,469 wetlands were counted on the old photos for an average of 29.4/quarter section. On the recent photography 2,314 wetlands were counted for an average of 27.5/quarter section. This represents an average $6 \%$ loss of wetlands in all regions. The region with the highest loss was the Thickwood Hills $(29 \%)$, while at Redvers there was a $6 \%$ increase; the other three regions experienced losses of $7-16 \%$ (Table 1). 


\begin{tabular}{|c|c|c|c|c|}
\hline \multirow{2}{*}{ Region } & \multirow{2}{*}{$\begin{array}{c}\text { No. of Quarter } \\
\text { Sections Examined }\end{array}$} & \multicolumn{2}{|c|}{ Number of Wetlands } & \multirow{2}{*}{ Percent Loss/Gain } \\
\hline & & Old Photos & New Photos & \\
\hline Redvers & 20 & 807 & 854 & +6 \\
\hline Wadena & 23 & 605 & 561 & -7 \\
\hline Saskatoon & 18 & 530 & 493 & -7 \\
\hline Thickwood & 12 & 286 & 203 & -29 \\
\hline Melfort & 11 & 241 & 203 & -16 \\
\hline TOTAL & 84 & 2,469 & 2,314 & -6 \\
\hline
\end{tabular}

The recently ground-truthed transects at Redvers revealed a total of 223 wetlands, compared to 205 identified from the photos; a $92 \%$ level of accuracy in discriminating wetlands via air photo interpretation. Most of the wetlands which were missed on the air photos were small temporary basins and roadside wetlands.

We recognize that factors such as differences in wetland conditions between the time when the old and new photographs were taken as well as time of year when the photos were taken can affect results of such a study. In addition, our ability to detect small temporary ponds from aerial photographs could also lead to errors in estimating wetland numbers. However, the comparison with groundtruthed transects from the Redvers area indicates that the number of these wetlands which were missed by interpreting air photos is not high, particularly considering that the Redvers area has a very high density of small wetlands. ${ }^{1}$ Overriding these factors however is how wetland loss is defined. Defining cultivation of a wetland as loss would result in much higher estimates of wetland loss than did our examination of air photos for "permanent" loss. We believe that this study provides reasonably accurate information on rates of complete, long-term wetland loss caused by drainage or filling.

Discussion Our results show that permanent wetiand loss since the 1940s in Saskatchewan averages 6\% with substantial variation among regions. The variation in loss rates among regions, from $+6 \%$ at $\mathrm{Red}$ vers to $-29 \%$ in the Thickwood Hills (Table 1), demonstrates how results can be affected by factors such as annual variation in wetland conditions (e.g. the wet spring in Redvers in 1986 when the photos were taken) or a high rate of land alteration such as the extensive bush clearing, drainage and filling which was evident in the Thickwood Hills area. The northernmost two areas exhibit the highest loss rates in this study (Thickwood and Melfort). This may be a result of relatively recent change (i.e. post-1940s) compared to more southerly areas (i.e. pre1940s).

An estimate of $40 \%$ wetland loss on the Canadian prairies is often cited, ${ }^{9}$ considerably higher than that revealed by this study and several others (Table 2). Only two of the studies we reviewed reported a loss rate of $40 \%$ or higher. It is noteworthy that both of those studies looked at the area of wetlands lost, not the number of wetlands lost. In the aspen parkland of Alberta, drainage on a relatively small 109-ha area from the turn of the century was estimated at $61 \%$ of the original wetland area with $81 \%$ of this having been drained by $1950 .^{13}$ In the Minnedosa pothole region of southwestern Manitoba, a 


\begin{tabular}{|c|c|c|c|c|}
\hline \multicolumn{5}{|c|}{$\begin{array}{l}\text { Table 2. COMPARATIVE STUDIES OF LAND USE CHANGE AND WETLAND LOSS IN THE } \\
\text { PRAIRIE PROVINCES }\end{array}$} \\
\hline \multirow{2}{*}{ Study Area } & \multirow{2}{*}{ Period } & \multicolumn{2}{|c|}{ Wetland Lost } & \multirow{2}{*}{ Comments } \\
\hline & & Area $(\%)$ & Number $(\%)$ & \\
\hline Alberta Aspen Parkland & $1900-1970^{13}$ & 61 & - & $\begin{array}{l}\text { survey plans, drainage maps, } \\
\text { air photos and field and air } \\
\text { surveys, } 109 \text { ha area, } 81 \% \\
\text { drained by } 1950, \text { wetlands less } \\
\text { than } 0.8 \text { ha not included }\end{array}$ \\
\hline \multirow[t]{3}{*}{$\begin{array}{l}\text { Minnedosa Pothole Region, } \\
\text { Manitoba }\end{array}$} & $1964-1974^{10}$ & 41 & - & $\begin{array}{l}12 \text { roadside transects, air } \\
\text { photos and field survey, } 3 \text { land } \\
\text { use classes } \\
\text { updates of Kiel et al. }\end{array}$ \\
\hline & $1974-1982^{11}$ & 33 & - & \\
\hline & 1928-1982 & 70 & - & overall loss ${ }^{6,10,11}$ \\
\hline $\begin{array}{l}\text { Black Soil Zone of the Prairie } \\
\text { Provinces }\end{array}$ & $1940-1970^{3}$ & 13 & 4.5 & $\begin{array}{l}600 \text { quarter sections, air } \\
\text { chotos and field } \\
\text { reconnaissance, individual } \\
\text { pond records }\end{array}$ \\
\hline $\begin{array}{l}\text { Minnedosa Pothole Region, } \\
\text { Manitoba }\end{array}$ & $1948-1970^{12}$ & -4 & - & $\begin{array}{l}\text { air photos and field investiga- } \\
\text { tions, } 5 \text { cover classes, } 23 \mathrm{~km}^{2}\end{array}$ \\
\hline Newdale Plain, Manitoba & $1964-1974^{2}$ & $\begin{array}{l}\text { area and } \\
\text { perimeter } \\
\text { increased }\end{array}$ & 7 & $\begin{array}{l}20 \text { sample plots at } 65 \text { ha each, } \\
\text { air photos, } 7 \text { cover classes, } \\
\text { wetland loss offset by gain in } \\
\text { temporary ponds }\end{array}$ \\
\hline $\begin{array}{l}\text { NAWMP Key Program Areas } \\
\text { in Saskatchewan (this study) }\end{array}$ & $1947-1992$ & - & 6 & 84 quarter sections, air photos \\
\hline
\end{tabular}

$41 \%$ loss of wetland area was reported between 1964 and 1974 based on the roadside transects of Kiel et al. ${ }^{6,10}$ An update on that same area revealed a $70 \%$ loss of wetland area from 1928-1982. ${ }^{11}$ Roadside transects may be biased towards high wetland loss because such wetlands may be destroyed by roadbuilding activity and drainage may be aided by the proximity of roadside ditches.

Within smaller areas of the Minnedosa pothole region, where high losses of wetland area have been reported, the findings of other studies show conflicting results to those studies which were based on roadside surveys. In a study of nine sections south of the town of Minnedosa, water area increased from $4 \%$ to $8 \%$ between 1948 and $1970 .{ }^{12}$ Another study of the same area found no appreciable change in wetland numbers between 1964-1974 but did detect an increase in both wetland area and perimeter. ${ }^{2}$ A study of the black soil zone of the prairie provinces (which included our study area) found a $13 \%$ loss of wetland area and a $4.5 \%$ loss of wetland numbers between 1940 and $1970 .^{3}$ Thus it appears that studies of loss of wetland area show much more variability and often higher loss rates than do studies which look at loss of wetland numbers.

Comparisons of wetland loss among different studies may be complicated by site-specific differences (ie. an area could have a topography which is particularly conducive to drainage or may have experienced a high drainage rate for other reasons) as well as varying methods of estimating and defining loss. Other potential sources of variation are differences in annual conditions (ie. wet versus dry years) and time of year that wetland comparisons are made (ie. wetland numbers and area typically decrease from spring to fall). 


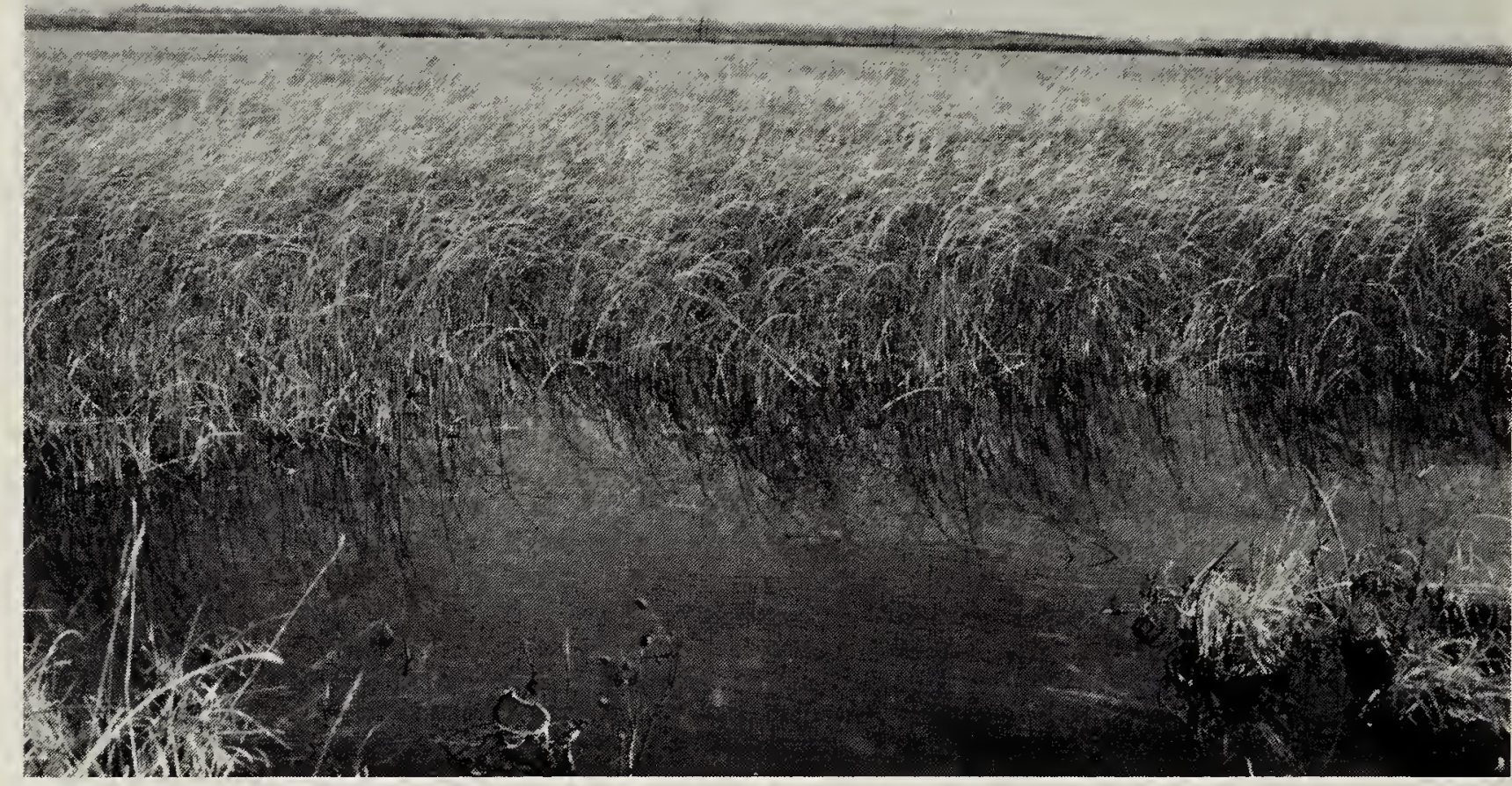

The permanent loss of wetland basins or depressions in Saskatchewan parkland resulting from drainage or complete filling between the 1940 s and early 1990s would appear to be in the order of $10 \%$ although it may be considerably higher in more northerly regions. Turner et al. ${ }^{15}$ reported a $0.19 \%$ annual rate of drainage in Saskatchewan which translates to a $7 \%$ loss rate over a 40 year span, similar to our study. Goodman and Pryor's ${ }^{3}$ 4.5\% loss over 30 years is also similar in magnitude. However, more transitory impacts on wetland basins, such as cultivation of primarily ephemeral ponds, have functionally destroyed 35$50 \%$ of Saskatchewan wetlands. ${ }^{1,15}$ Eliminating wetland vegetation through cultivation results in decreased snow catchment, increased soil and water erosion, and destruction of the plant life and aquatic invertebrates which form the basis of the wetland ecosystem. ${ }^{5,8,14}$

A high degree impact on wetland margins was evident over the 40year span examined in this study. The clearing of bush and the cultiva- tion of dry temporary wetlands were two obvious major changes. Rapid degradation of wetland basins and margins continues. Such activity eliminates native vegetation and hence wildlife habitat. The hardest hit are shallow temporary ponds which are easily cultivated but are preferred habitat for many species of ducks. ${ }^{4}$

1. ADAMS, G.D. and A.B. DIDIUK. 1993. Prairie pothole project - Redvers. Evaluation of habitat trends in the Antler municipality and adjoining control area - 1987-1990. Unpubl. Can. Wild. Serv. Report. 20 pp+.

2. ADAMS, G.D. and G.C. GENTLE. 1978. Spatial changes in waterfowl habitat, 1964-1974, on two land types in the Manitoba Newdale Plain. Can. Wildl. Serv. Occas. Paper No. 38. 29 pp.

3. GOODMAN, A.S. and S.P. PRYOR. 1972. A preliminary study of the methods and rates of alteration of waterfowl habitat in the black soil zone of Western Canada. Unpubl. Can. Wildl. Serv. Report. 77 pp.

4. JOHNSON, D.H. and J.W. GRIEP. 1988. Determinants of breeding distributions of ducks. Wildl. Monogr. 100:1-37. 
5. KAMINSKI, R.M. and H.H. PRINCE. 1981. Dabbling duck and aquatic macroinvertebrate responses to manipulated wetland habitat. J. Wild. Manage. 45:1-15.

6. KIEL, W.H. Jr., A.S. HAWKINS and N.G. PERRET. 1972. Waterfowl habitat trends in the aspen parkland of Manitoba. Can. Wildl. Serv. Report Series No. 18. 61 pp.

7. LYNCH-STEWART, P. 1983. Land use change on wetlands in southern Canada: review and bibliography. Canada land use monitoring program. Lands Directorate. Environment Canada. Working Paper No. 26.

8. MILLAR, J.B. 1969. Observations on the ecology of wetland vegetation. Pp. $49-56$ in Saskatoon wetlands seminar. Can. Wildl. Serv. Report Series No. 6. 262 pp.

9. NATIONAL WETLANDS WORKING GROUP. 1988. Wetlands of Canada. Ecological Land Classification Series No. 24. Sustainable Development Branch, Environment Canada, Ottawa, Ontario and Polyscience Publications Inc., Montreal, Quebec. 452 pp.

10. RAKOWSKI, P., R.W. NERO, and R.C. HUTCHISON. 1974. Present status of waterfowl habitat in the prime duck production area of Manitoba. Unpubl. Can. Wildl. Serv. Report. 12 pp.
11. RAKOWSKI, P.W. and B.P. CHABOT. 1983. Changes in land use in the Minnedosa district of southwestern Manitoba: an update on the KielHawkins transects. Unpubl. Can. Wildl. Serv. Report, Winnipeg, Manitoba. $10 \mathrm{pp}$.

12. ROUNDS, R.C. 1982. Land use changes in the Minnedosa pothole region of southwestern Manitoba 19481970. Blue Jay 40:6-12.

13. SCHICK, C.D. 1972. A documentation and analysis of wetland drainage in the Alberta Parkland. Unpubl. Can. Wildl. Serv. Report. 15 pp.

14. SWANSON, G.A. and H.F. Duebbert Wetland habitats of waterfowl in the prairie pothole region. In: van der Valk A, editor. Northern prairie wetlands. lowa State University Press, Ames. 1989. Pp. 228-267.

15. TURNER, B.C., G.S. HOCHBAUM, F.D. CASWELL, and D.J. NIEMAN. 1987. Agricultural impacts on wetland habitats on the Canadian Prairies, 1981-85. Trans. N. Amer. Wildl. and Natur. Resour. Conf. 52:206-215.

16. UNITED STATES DEPARTMENT OF THE INTERIOR AND ENVIRONMENT CANADA. 1986. North American waterfowl management plan: a strategy for cooperation. $19 \mathrm{pp}$.

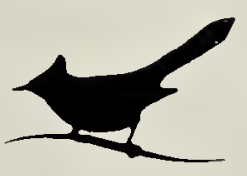

Maximum butterfly longevity: Cabbage Butterfly: 3 days for female/17 for male; Tiger Swallowtail, 3/12; Spring Azure, 4/2; Orange Sulphur, 14/25; Viceroy, -117; Great Spangled Fritillary, -122. Paul Opler and George Krizek, Butterflies East of the Great Plains. 